\title{
Public Open Spaces in North Sumatra Province
}

\author{
Achmad Delianur Nasution*, Wahyuni Zahrah \\ Department of Architecture, Faculty of Engineering, \\ University of Sumatera Utara \\ aan.nasution@gmail.com
}

\begin{abstract}
Since the regions in North Sumatra Province, Indonesia, become more urbanized, commercial centers grow up. In contrast, public open space (POS) tends to decline. In this condition, the study aim is to explore the public life that goes on. Through field observation, the research collected physical quality of POS and the variation and intensity of activities that community did there. The results showed that almost all of the POS design did not refer to the criteria of successful POS. However, people utilize the POS intensively and meet their needs, both in the good and poor quality of the POS.
\end{abstract}

Keywords: Public life; public open space; small towns; North Sumatra

eISSN: 2398-4295 @ 2017. The Authors. Published for AMER ABRA by e-International Publishing House, Ltd., UK. This is an open access article under the CC BY-NC-ND license (http://creativecommons.org/licenses/by-ncnd/4.0/). Peer-review under responsibility of AMER (Association of Malaysian Environment-Behaviour Researchers), ABRA (Association of Behavioural Researchers on Asians) and CE-Bs (Centre for EnvironmentBehaviour Studies), Faculty of Architecture, Planning \& Surveying, UniversitiTeknologi MARA, Malaysia.

https://doi.org/10.21834/ajbes.v2i5.48 


\subsection{Introduction}

\subsection{Background}

The city life shows that many people do their activities in the public open spaces (POS), such as streets, pedestrian paths, parks and squares (Whyte, 1980, Gehl, 1996). Many scholars have proven the benefits of the activities, such as improving social cohesion, as well as physical and psychological health. Even, the unwell-planned public open space still gives a positive contribution to people quality of life (Nasution and Zahrah, 2014). The study about how people use POS relates to the quality of the POS (Karuppannan dan Asivan, 2013; Zakariya et al., 2014; Ngesan dan Zubir, 2015; Malek et al., 2015).

\subsection{Objective}

The aim of the study is to explore the utilization of POS in small towns in North Sumatra province that configure public life. The study investigates the activities going on at POS, people who visit the place and the quality of facility and design relate to it. Moreover, the study also measures user satisfaction of POS to identify whether the area meets people needs.

\subsection{Literature Review}

The study of public life means to take a look at how people use the urban space (Gehl, 1996). It can describe the changing of urban design related to the utilization, for example, what Gehl investigated in Copenhagen city center. A few years before Gehl's project, William H. Whyte (1980), carried out the study why and how urban space being utilized and 'life', meanwhile the others 'empty'. Refer to Gehl (1996), the successful public space characterized by the larger optional recreational activities than necessary activities. Moreover, people used it frequently (Jacobs, 2008) and involved a various social background of citizens (Whyte, 1980).

There are some aspects relate to the quality of POS, such as accessibility, facility, function/activity, management, and climate comfort (PPS, 2000; Nasution and Zahrah, 2014). The good quality of POS will drive people to use it more intensively (Gehl, 1996; Whyte, 1980; Sakip et al., 2014). However, the premise does not apply to all places and cases. The study for neighborhood open space in Singapore, Delhi, and Kuala Lumpur that held by Karuppannan and Sivarn (2013) showed that the utilization of POS does not directly relate to its quality. The similar facts found in POS of Medan, North Sumatra, either in the urban-scale (Nasution and Zahrah, 2014) and neighborhood scale POS (Nasution and Zahrah, 2014).

The main difference POS of any place outside Indonesia, particularly in the developed country, is the POS are well planned and designed. In Indonesia, the design professionals - 
e.g. architect, landscape architect, urban designer - have not a proper role in designing urban space.

\subsection{Methodology}

\subsection{Respondents}

The study took place in twelve small towns' POS in North Sumatra Province. They are Binjai, Stabat, Lubuk Pakam, Sei Rampah, Pematang Siantar, Brastagi, Batubara, Kisaran, Sipirok, Pandan, Sibolga, and Tarutung. The study area was the active urban-scale POS, showed by the activities occurred at those places. Most of the POS were the squares; two of the POS are a park and a river promenade. There were 781 respondents in the POS that interviewed. The surveyors chose them randomly at the activities zone.

\subsection{Variables and data collecting}

The study collected the data at the weekend in March 2015, while the utilization of POS reached the peak. The observation recorded the quality of the POS, such as the accessibility, the facility, the function and activity, the natural elements, and the management. Except the management factor, four of the five variables that indicate the quality of POS, are the elements of design. People who agreed to participate in the survey filled a set of the questionnaire consisted of the questions about demographic background and the intensity of the utilization of POS. The field survey measured people perception that based on the 5 points Likert scale, from 5 to 'very satisfied' to 1 'very unsatisfied'. The mean- score of each variable indicated the level of satisfaction.

\subsection{Results and Discussions}

\subsection{Study area}

North Sumatra province is a region that mostly rural. Agriculture and plantation are the major economic income of the province. In the era of Dutch Colonial, there were just six autonomy towns. The others are the Kecamatan-towns as the capitals of the regencies. When the government applied autonomy regulation since 1999, the new regencies with the new urbanized areas have been rising. Those areas characterized by the denser commercial districts.

Most of the urban-scale POS in the province are the squares, as the typical features of the government complex since the Dutch era. It is functioned as the center of the government and public facility buildings around them. The city hall, grand mosque, and town/regency parliament houses are some of the typical buildings around the square. This place becomes the venue of the official nation-ceremonies, such as Independence Day and 
the National Hero Day. However, the daily function of the squares is the public area where people socialize, exercise and play.

\subsection{Respondents characteristics}

There were 781 respondents participated in the survey. They were mostly the local residence, the youth of $16-20$ years old, and students. The male is larger $(55.70 \%)$ than female $(44.30 \%)$.

\subsection{Quality of POS}

\subsubsection{Facility}

Most of the POS were squares with typical rectangular shape and similar facilities. The ground cover was grass field, with a pendopo (a kind of open air building) for the official ceremonies purpose. The other facilities took place in one part of the squares, e.g. one of the corners, consisted of the seating area, pedestrian path/jogging track, children playground/tot lot, garden, and trees. There were street vendors in almost all squares, they usually sole foods and toys. Less than half of the squares had a complete facilities (Binjai, Sipirok, Stabat, Sibolga), such as the basketball and badminton fields, fitness/exercise instruments, and tot lots. The POS in Brastagi, Pandan, Rampah and Tarutung had the poorest facilities and design. The other POS had some facilities but had a lack management and maintenance. Except the POS OF Brastagi and Rampah (mean score lower than 3), the satisfaction level with the facilities were fair, with average rating 3 or more, but not reach 4 . The highest satisfaction level found in Stabat (mean score 3.5), although the facilities were not better than Kisaran, Binjai, and Sipirok (Table 1).

Table 1. POS facilities

\begin{tabular}{lcccccccc}
\hline POS & \multicolumn{7}{c}{ POS Facilities } & Des \\
\cline { 2 - 7 } & Par & Toi & Grf & Ped & Ben & Ost & Exe & \\
\hline Bat & - & $\sqrt{n}$ & $\sqrt{ }$ & $\sqrt{ }$ & $\sqrt{ }$ & $\sqrt{ }$ & - & Fair \\
\hline Bra & - & $\sqrt{ }$ & $\sqrt{ }$ & - & $\sqrt{ }$ & $\sqrt{ }$ & - & Poor \\
\hline Bin & $\sqrt{n}$ & $\sqrt{ }$ & $\sqrt{ }$ & $\sqrt{ }$ & $\sqrt{ }$ & $\sqrt{ }$ & - & Fair \\
\hline Kis & $\sqrt{ }$ & $\sqrt{ }$ & $\sqrt{ }$ & $\sqrt{ }$ & $\sqrt{ }$ & $\sqrt{ }$ & $\sqrt{ }$ & Good \\
\hline Lub & - & $\sqrt{ }$ & $\sqrt{ }$ & $\sqrt{ }$ & $\sqrt{ }$ & $\sqrt{ }$ & $\sqrt{ }$ & Poor \\
\hline Pan & $\sqrt{ }$ & $\sqrt{ }$ & $\sqrt{ }$ & - & - & $\sqrt{ }$ & - & Poor \\
\hline Pem & - & $\sqrt{ }$ & $\sqrt{ }$ & $\sqrt{ }$ & $\sqrt{ }$ & - & - & Poor \\
\hline Sip & $\sqrt{ }$ & $\sqrt{ }$ & $\sqrt{ }$ & $\sqrt{ }$ & $\sqrt{ }$ & - & - & Good \\
\hline Sta & $\sqrt{ }$ & $\sqrt{ }$ & $\sqrt{ }$ & $\sqrt{ }$ & $\sqrt{ }$ & $\sqrt{ }$ & - & Fair \\
\hline Tar & - & - & - & $\sqrt{ }$ & $\sqrt{ }$ & - & - & Poor \\
\hline Sib & - & $\sqrt{ }$ & $\sqrt{ }$ & $\sqrt{ }$ & $\sqrt{ }$ & $\sqrt{ }$ & $\sqrt{ }$ & Fair \\
\hline Ramp & - & $\sqrt{ }$ & $\sqrt{ }$ & $\sqrt{ }$ & - & - & - & Poor \\
\hline
\end{tabular}


Nasution, A.D., \& Zahrah, W. / Asian Journal of Behavioural Studies, AjBeS, 2(5), Jan / Mar 2017 (p.45-54)

\begin{tabular}{lccccccl}
\hline POS & \multicolumn{9}{c}{ POS Facilities } & Des \\
\cline { 2 - 6 } & Bas & Tot & Stv & Mos & Gar & Tre & \\
\hline Bat & - & - & $\sqrt{ }$ & $\sqrt{ }$ & $\sqrt{ }$ & $\sqrt{ }$ & Fair \\
\hline Bra & - & - & $\sqrt{ }$ & & & $\sqrt{ }$ & Poor \\
\hline Bin & $\sqrt{n}$ & $\sqrt{ }$ & $\sqrt{ }$ & $\sqrt{ }$ & $\sqrt{ }$ & $\sqrt{ }$ & Fair \\
\hline Kis & $\sqrt{ }$ & - & - & - & $\sqrt{ }$ & $\sqrt{ }$ & Good \\
\hline Lub & - & - & - & - & $\sqrt{ }$ & $\sqrt{ }$ & Poor \\
\hline Pan & - & - & $\sqrt{ }$ & - & - & $\sqrt{ }$ & Poor \\
\hline Pem & - & - & $\sqrt{ }$ & $\sqrt{ }$ & $\sqrt{ }$ & $\sqrt{ }$ & Poor \\
\hline Sip & $\sqrt{ }$ & $\sqrt{ }$ & $\sqrt{ }$ & & $\sqrt{ }$ & $\sqrt{ }$ & Good \\
\hline Sta & - & $\sqrt{ }$ & $\sqrt{ }$ & $\sqrt{ }$ & $\sqrt{ }$ & $\sqrt{ }$ & Fair \\
\hline Tar & - & - & $\sqrt{ }$ & - & $\sqrt{ }$ & $\sqrt{ }$ & Poor \\
\hline Sib & $\sqrt{ }$ & $\sqrt{ }$ & $\sqrt{ }$ & - & $\sqrt{ }$ & $\sqrt{ }$ & Fair \\
\hline Ramp & - & - & $\sqrt{ }$ & - & - & $\sqrt{ }$ & Poor \\
\hline
\end{tabular}

Par $=$ Parking lot

Toi $=$ Toilet

$\mathrm{Grf}=$ Grass field

Ped $=$ Pedestrian path

Ben= Bench/ outdoor seating
Ost $=$ Open stage $/$ pendopo

Exe $=$ Exercise/fitness

$$
\text { instrument }
$$

Bas $=$ Basketball Arena

Tot $=$ Tot lot

Stv $=$ Street vendor
Mos $=$ Mosque

Gar $=$ Garden

Tre $=$ Trees

Des $=$ Design

quality

Table 2. Mean score of people satisfaction with POS facilities

\begin{tabular}{llllllll}
\hline \multirow{2}{*}{ Variable } & \multicolumn{7}{c}{ Public Open Space } \\
\cline { 2 - 9 } & Bat & Bra & Bin & Kis & Lub & Pan & Pem \\
\hline \multicolumn{1}{c}{1} & 2 & 3 & 4 & 5 & 6 & 7 & 8 \\
\hline Dimension/widht & 3,88 & 3,70 & 3,27 & 4,00 & 4,06 & 3,75 & 3,60 \\
\hline Parking lot & 3,50 & 2,61 & 2,87 & 3,84 & 3,31 & 3,40 & 2,99 \\
\hline Pedestrian path & 3,63 & 2,77 & 3,43 & 3,81 & 3,61 & 3,44 & 3,50 \\
\hline Toilet & 3,28 & 1,77 & 2,17 & 2,30 & 2,03 & 3,07 & 2,14 \\
\hline Playing area & 3,65 & 3,33 & 3,24 & 3,20 & 3,61 & 3,59 & 3,27 \\
\hline Sport/exer. Area & 3,79 & 3,77 & 3,46 & 3,73 & 3,73 & 3,69 & 3,29 \\
\hline Sitting area & 3,90 & 3,21 & 3,46 & 3,54 & 3,76 & 3,85 & 3,61 \\
\hline Garden area & 3,72 & 2,94 & 3,31 & 3,64 & 3,79 & 3,71 & 3,60 \\
\hline Picnic area & 3,43 & 2,60 & 2,94 & 2,90 & 3,36 & 3,46 & 3,24 \\
\hline Mosque/praying area & 3,84 & 2,60 & 3,39 & 2,71 & 3,09 & 3,39 & 2,46 \\
\hline Dining area & 3,63 & 3,20 & 3,36 & 2,16 & 3,23 & 3,37 & 3,39 \\
\hline Street vendor & 3,47 & 2,86 & 3,01 & 3,57 & 3,04 & 3,40 & 3,00 \\
\hline Average & 3,64 & 2,95 & 3,16 & 3,28 & 3,39 & 3,51 & 3,17 \\
\hline
\end{tabular}

\begin{tabular}{lrrrrrr}
\hline \multirow{2}{*}{ Variable } & \multicolumn{7}{c}{ Public Open Space } \\
\cline { 2 - 7 } & Sip & Sta & Tar & Sib & Ram & Aver. \\
\hline & 9 & 10 & 11 & 12 & 13 & 14 \\
\hline Dimension/widht & 3,67 & 3,86 & 3,26 & 4,25 & 3,57 & 3,74 \\
\hline Parking lot & 3,44 & 3,56 & 3,07 & 3,84 & 2,47 & 3,27 \\
\hline Pedestrian path & 3,42 & 3,54 & 3,10 & 4,32 & 3,30 & 3,49 \\
\hline
\end{tabular}


Nasution, A.D., \& Zahrah, W. / Asian Journal of Behavioural Studies, AjBeS, 2(5), Jan /Mar 2017 (p.45-54)

\begin{tabular}{lllllll}
\hline Toilet & 2,90 & 2,07 & 2,47 & 2,14 & 2,00 & 2,41 \\
\hline Playing area & 3,54 & 3,66 & 2,81 & 4,09 & 2,53 & 3,38 \\
\hline Sport/exer. Area & 3,33 & 3,64 & 2,99 & 4,23 & 4,03 & 3,65 \\
\hline Sitting area & 3,63 & 3,54 & 3,53 & 3,39 & 3,93 & 3,62 \\
\hline Garden area & 3,76 & 3,63 & 3,11 & 3,28 & 2,50 & 3,43 \\
\hline Picnic area & 3,63 & 3,36 & 2,73 & 2,75 & 2,07 & 3,06 \\
\hline Mosque/praying area & 3,36 & 3,57 & 3,21 & 2,64 & 2,00 & 3,05 \\
\hline Dining area & 3,16 & 3,84 & 3,40 & 4,05 & 3,63 & 3,36 \\
\hline Street vendor & 2,69 & 3,71 & 3,24 & 4,16 & 3,83 & 3,34 \\
\hline Average & 3,38 & 3,50 & 3,08 & 3,60 & 2,99 & 3,32 \\
\hline
\end{tabular}

\subsubsection{Accessibility}

Most of the POS had no proper accessibility, due to the absence of pedestrian linkage and public transport integration (Project for Public Spaces, 2000; Gehl 2002; CABE dan DETR, 2001). The only appropriate aspect of accessibility was the clear gates. There was no controlling or filtering of the visitors. The POS was mainly surrounded by roads. Thus, the place seemed like an 'alienated island'. However, the POS were not so hard to be reached due to the not so busy traffic, at least if it compared with Medan (Nasution and Zahrah, 2014). With these conditions, all aspects of accessibility were generally perceived at a fine level (the satisfaction level more than 3 , though the satisfaction level did not reach 4 . The fact related to the people's circulation habit that more preferred private vehicle (primarily motorcycle) than walking or public transport, even though the distance from home was less than 500 meters. Only two POS (Brastagi and Pematang Siantar) that the majority of visitors came to the POS by walk. Since most of the respondents used the motorcycle to get to the POS, there were no problems with the distance. Though many respondents lived more than $5 \mathrm{~km}$ from POS, they were generally satisfied with the accessibility aspects, including distance (Table 3). The fact was similar with capital city Medan (Nasution dan Zahrah, 2013), so it can be said that motorcycling is one of people's fashion in North Sumatra region. The reality is different with the nature of many POS in other places, particularly those of developed countries. In those cases, the POS are good quality if having the proper pedestrian linkage.

Table 3. Mean score of people satisfaction with POS accessibility

\begin{tabular}{lccccc}
\hline $\begin{array}{c}\text { Public } \\
\text { Open } \\
\text { Space }\end{array}$ & Distance & $\begin{array}{c}\text { Easy } \\
\text { entering }\end{array}$ & $\begin{array}{c}\text { Transporta } \\
\text { tion }\end{array}$ & Traffic & Average \\
\cline { 2 - 6 } Bat & 3,65 & 3,76 & 3,73 & 3,49 & 3.66 \\
\hline Bra & 3,21 & 3,49 & 3,47 & 3,53 & 3.43 \\
\hline Bin & 3,34 & 3,79 & 3,79 & 3,54 & 3.62 \\
\hline Kis & 3,34 & 3,79 & 3,70 & 3,70 & 3.63 \\
\hline Lub & 3,54 & 3,65 & 3,54 & 3,64 & 3.59 \\
\hline Pan & 3,34 & 3,57 & 3,47 & 3,31 & 3.42 \\
\hline Pem & 3,36 & 3,67 & 3,76 & 3,96 & 3.69 \\
\hline Sip & 3,12 & 3,34 & 3,47 & 3,72 & 3.41 \\
\hline
\end{tabular}




\begin{tabular}{llllll}
\hline Sta & 3,20 & 3,81 & 3,57 & 3,81 & 3.60 \\
\hline Tar & 3,24 & 3,36 & 3,30 & 3,27 & 3.29 \\
\hline Sib & 3,77 & 4,14 & 4,02 & 4,00 & 3.98 \\
\hline Tan & 3,64 & 3,89 & 3,62 & 3,77 & 3.73 \\
\hline Ram & 3,03 & 3,83 & 3,73 & 3,63 & 3.56 \\
\hline Average & 3,37 & 3,70 & 3,63 & 3,64 & 3.59 \\
\hline
\end{tabular}

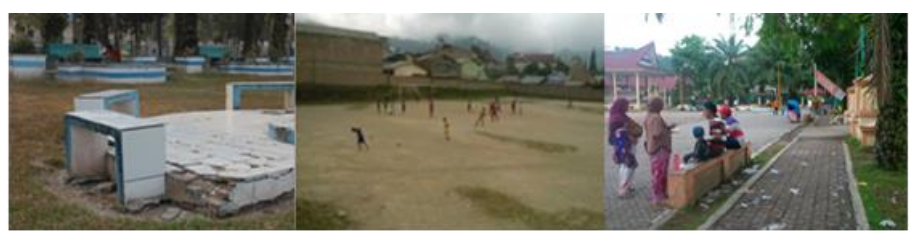

(a)

(b)

(c)

Figure 1. Some of poor design and maintenance facilities in (a) Lubuk Pakam (b) Brastagi (c) Sibolga

\subsubsection{Climate comfort}

The climate comfort relates to the presence of trees, garden, and the sun heat and rain protector. One of the features that fill almost the POS is trees and grass field. There were some trees in the seating area of some POS. Thus, they shadowed the spot below from sun heat. However, at some POS, the trees did not meet people needs, because of the number, distribution, and the quality. The people satisfaction level of this features were below 3 in Batubara, Brastagi, Tarutung, and Sibolga. However the rest were perceived good, but the mean scores were below 4 (table 4). The satisfaction level for rain protector is the lowest, since, except pendopo, there was no construction with canopy in almost all the POS.

Table 4. Mean score of people satisfaction with climate comfort

\begin{tabular}{lccccc}
\hline $\begin{array}{c}\text { Public } \\
\text { Open } \\
\text { Space }\end{array}$ & Trees & $\begin{array}{c}\text { Wind } \\
\text { velocity }\end{array}$ & Sun-shading & $\begin{array}{c}\text { Rain } \\
\text { protecting }\end{array}$ & Average \\
\cline { 2 - 6 } Bat & 2,69 & 3,50 & 2,81 & 2,97 & 2,99 \\
\hline Bra & 2,66 & 3,24 & 2,27 & 2,16 & 2,58 \\
\hline Bin & 3,49 & 3,64 & 3,19 & 2,77 & 3,27 \\
\hline Kis & 3,24 & 3,73 & 2,70 & 2,37 & 3,01 \\
\hline Lub & 4,01 & 3,64 & 3,43 & 3,03 & 3,53 \\
\hline Pan & 3,04 & 3,57 & 3,06 & 3,29 & 3,24 \\
\hline Pem & 4,03 & 3,99 & 3,75 & 2,96 & 3,68 \\
\hline Sip & 3,98 & 4,13 & 3,78 & 3,48 & 3,84 \\
\hline Sta & 3,86 & 3,79 & 3,24 & 2,83 & 3,43 \\
\hline Tar & 2,99 & 3,33 & 3,23 & 3,20 & 3,19 \\
\hline Sib & 2,36 & 3,57 & 1,95 & 2,12 & 2,50 \\
\hline Tan & 3,76 & 3,75 & 3,75 & 3,48 & 3,57 \\
\hline Ram & 3,47 & 3,70 & 3,53 & 3,57 & 3,27 \\
\hline Average & 3,35 & 3,66 & 3,13 & 2,94 & 2,99 \\
\hline
\end{tabular}




\subsection{Public life}

The people came to the POS were vary in age, but most of them were teenagers. They came to the POS in a group, indicated that they were socializing. The people utilized POS frequently, mainly 1-3 times a week, and stayed there for 1-2 hours. The facts were similar with capital city Medan (Nasution and Zahrah, 2014). However, not like Medan, the utilization of the POS was intensive until night. The most activities going on in the POS was sport/exercising, such as jogging, walking, aerobic gymnastic, fitness, cycling. People also played various game-sports, such as football, basketball, volleyball, badminton, roller skate and the skateboard. However, there were not always the adequate facilities for such games. Grass field became a multi-purpose ground for many kinds of games, but pendopo also became the arena for skateboard, roller blade and badminton.

The other favorite activity was sitting. Most of the POS had the facility, except Rampah and Pandan. People sat everywhere they could sit; not just on the seating equipment, but also on the grass field, pendopo steps, the garden or pedestrian path barrier, even on the motorcycle.

Besides teenagers, the most visitors of POS were children. They came to the POS did not always relate to the presence of tot lot. Rampah and Brastagi, which had no children playground and its equipment, still utilized by children. The fact indicated that the activity in the POS did not always directly relate to the quality (Karuppannan dan Sivarn, 2013; Nasution and Zahrah, 2013, 2014).

On average, people were satisfied with function and activities of POS, even the poor quality POS in Rampah and Brastagi, which had a lower satisfaction level for facilities. The fact showed that people felt that the POS met their needs, though it had not reached an optimal level. (Table 5)

Table 5. Mean score of people satisfaction with POS function/activity

\begin{tabular}{|c|c|c|c|c|c|}
\hline \multirow{2}{*}{$\begin{array}{l}\text { Public } \\
\text { Open } \\
\text { Space }\end{array}$} & \multicolumn{5}{|c|}{ Variable } \\
\hline & Recreation & Sport/exercise & Socialization & Politic & Average \\
\hline Bat & 3,52 & 3,91 & 3,72 & 3,31 & 3.62 \\
\hline $\mathrm{Bra}$ & 2,96 & 4,04 & 3,39 & 3,03 & 3.36 \\
\hline Bin & 3,31 & 3,51 & 3,51 & 2,99 & 3.33 \\
\hline Kis & 3,57 & 3,96 & 3,66 & 2,96 & 3.54 \\
\hline Lub & 3,40 & 3,96 & 3,61 & 2,99 & 3.49 \\
\hline Pan & 3,40 & 3,69 & 3,49 & 3,21 & 3.45 \\
\hline Pem & 3,24 & 3,47 & 3,56 & 2,77 & 3.26 \\
\hline Sip & 3,70 & 3,48 & 3,53 & 3,33 & 3.51 \\
\hline Sta & 3,61 & 3,73 & 3,76 & 3,21 & 3.58 \\
\hline Tar & 3,17 & 3,14 & 3,23 & 3,10 & 3.16 \\
\hline Sib & 2,93 & 4,09 & 3,98 & 2,95 & 3.49 \\
\hline Tan & 3,40 & 3,77 & 3,70 & 2,41 & 3.32 \\
\hline Ram & 2,75 & 3,77 & 4,07 & 2,97 & 3.39 \\
\hline Aver & 3,30 & 3,73 & 3,63 & 3,02 & 3.42 \\
\hline
\end{tabular}




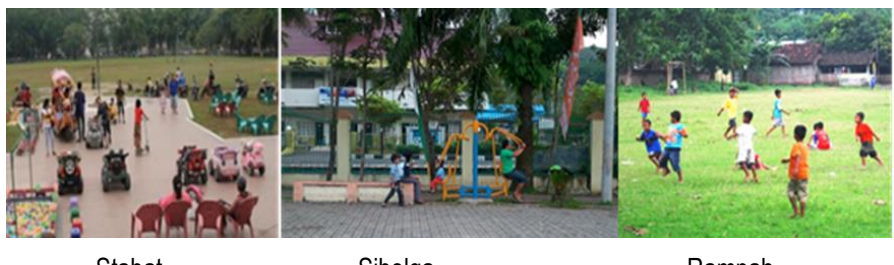

Stabat Sibolga Rampah

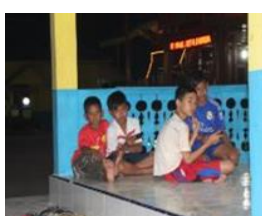

Binjai

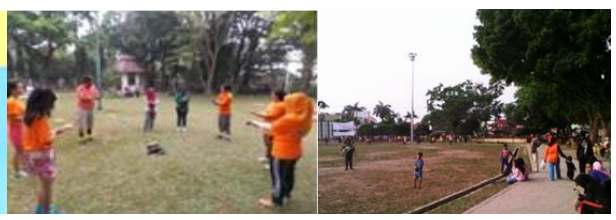

Pematang Siantar

Batubara

Fig. 2. Examples of public life within the district

\section{0 Conclusion}

The result of the study shows that public life in small towns' POS of North Sumatra province was going on intensively, with or without an adequate quality of design, facility, and management. It is similar with Medan, where people have no many choices for free access place in the city. The research confirms several similar studies about the quality of POS and the livability (Karuppannan and Sivam, 2013, Nasution and Zahrah, 2013, 2014). It is necessary for the government to place the POS as one of the development priorities.

\section{Acknowledgement}

This research was supported by Ministry of National Education of Indonesian Republic through Hibah Bersaing research grant. Thank you for all surveyors and participants for their precious contributions.

\section{References}

Gehl, J., \& Gemzoe, L. (1996). Public Spaces - Public Life. The Danish Architectural Press, And The Royal Danish Academy of Fine Arts, School of Architecture Publishers. Copenhagen

Harun, N. Z., Zakarya, K., Mansor, M., \& Zakaria, K. (2014). Determining attributes of urban plaza for social sustainability. Procedia - Social and Behavioral Sciences 153 (2014) 606-615. 
Ismail, W. A. W., \& Said, I. (2015). Integrating the community in urban design and planning of public spaces: a review in Malaysian cities. Procedia - Social and Behavioral Sciences 170 (2015) 357.364.

Jacobs, Jane, (1961) The Death And Life of Great American Cities, New York: Random House

Jurkovic, N. B. (2014). Perception, experience and the use of public urban space by residents of urban neighbourhoods. Urbani Izziv, 25(1) pp. 107-125.DOI: 10.5379/urbani-izziv-en-2014-25-01-003

Karuppannan, S., \& Sivam, A. (2013). Comparative analysis of utilisation of open space at neighbourhood level in three Asian cities: singapore, delhi and kuala lumpur. Urban Design International Vol. 18, 2, 145-164.

Malek, N. A., Mariapan, M., \& Rahman, N. I. A. (2015). Community participation in quality assessment for green open spaces in Malaysia. Procedia - Social and Behavioral Sciences 168 (2015) 219 - 228.

Nasution, Achmad Delianur, Zahrah, Wahyuni (2012). Public open space privatization and quality of life, case study Merdeka Square Medan. Procedia - Social and Behavioral Sciences 36 (2012) 466 - 475

Nasution, Achmad Delianur, Zahrah, Wahyuni (2012). Neighborhood open space and quality of life in low-income settlement: Rahmadsyah Square case study, medan, Indonesia. Proceedings HABITechno International Seminar Innovation Housing and Settlement Technology. Bandung : ITB

Nasution, Achmad Delianur, Zahrah, Wahyuni (2014). Community perception on public open space and quality of life in Medan, Indonesia. Procedia - Social and Behavioral Sciences 153 (2014) 585 - 594

Ngesan, M. R., \& Zubir, S. S. (2015). Place identity of nighttime urban public park in Shah Alam and Putrajaya. Procedia - Social and Behavioral Sciences 170 (2015) 452-462.

PPS - Project for Public Spaces (2000) How to Turn a Place Around: A Handbook of Creating Successful Public Spaces, New York: Project For Public Space

Sakip, S. T. M., Akhir, N. M., \& Omar, S. S. (2015). Determinant factors of successful public parks in Malaysia. Procedia - Social and Behavioral Sciences 170 (2015) 422-432.

Whyte, W. H. (1980). The Social Life of Small Urban Spaces. The Conservation Foundation, Washington, D.C.

Zakariya, K., Harun, N. Z., \& Mansor, M. (2014). Spatial characteristics of urban square and sociability: a riview of the City Square, Melbourne. Procedia - Social and Behavioral Sciences 153 (2014) 678-688. 